\title{
Organizing State Protection of the Personnel of Penal Institutions in Some Countries of Western Europe, North America and Asia
}

\author{
OLEG V. KIRILOVSKII \\ Vologda Institute of Law and Economics of FSIN Russia, Vologda, Russian \\ Federation \\ ORCID: https://orcid.org/0000-0001-8718-396X, e-mail: kirilovskiy77@mail.ru
}

\begin{abstract}
Introduction: the paper investigates the experience of some countries of Western Europe (Italy, Germany, Austria and The Netherlands), North America (the U.S. and Canada) and Asia (Mongolia and Japan) in the field of state protection of penitentiary personnel. The aim of summarizing the experience of these countries is to identify relevant examples of legal regulation and organization of state protection of civil servants, including prison staff, for the purpose of implementation of this experience in Russian practice. Methods: we use general scientific (analysis, synthesis, induction, etc.) and specific sociological methods of cognition (comparative-legal, sociological, statistical, comparative). Results: having conducted the comparative study, we find that Mongolia and Japan do not have a separate unified legal framework for state protection of penitentiary personnel. The norms that establish the legal and social guarantees of employees are contained in several laws and by-laws that specify them. The experience of the countries of Western Europe and America indicates that the activities aimed at ensuring state protection are concentrated and implemented by a specially created body with a wide range of powers. In these countries, special attention is paid to the issue of separate funding of programs for the protection of state servant sand persons who assist justice. Discussion: we highlight the fact that the legal and organizational aspects of ensuring state protection of the personnel of penitentiary institutions in some foreign countries have positive aspects. Some examples of foreign experience can be used in law-making and law enforcement activities in the Russian Federation.

Keywords: penitentiary personnel; foreign experience; state protection; penal system; security measures; legal and social protection measures.
\end{abstract}

12.00.11 - Judicial activities, prosecutor's activities, human rights and law enforcement activities.

F or c it at i o n: Kirilovskii O.V. Organizing state protection of the personnel of penal institutions in some countries of Western Europe, North America and Asia. Penitentiary Science, 2021, vol. 15, no. 2 (54), pp. 405-412. DOI 10.46741/2686-9764-2021-15-2405-412.

\section{Introduction}

The current state of the penal system in Russia, as well as its reform in an unstable geopolitical situation, taking into account public spending optimization, points to new challenges, and also emphasizes the relevance of state protection of the interests of the employees of the penal system and their relatives.

Due to the necessity of face-to-face interaction with convicts, who often show a negative and often aggressive attitude, penal system employees are most susceptible to criminal encroachment on the part of criminally minded citizens. The relevance of the issue regarding the safety of personnel of institutions and bodies of the criminal justice system is obvious; this fact is confirmed by departmental statistics. Thus, in 2019, 300 (in 2018 - 175, in 2017 - 175, in 2016 - 194) cases of convicts' illegal actions (violence, threats, insults) directed against penitentiary staff were registered in the institutions of the penal system. Only in the first quarter of 2020, 98 cases of assaults were committed (in same period in the previous year -64).

Of particular concern are cases of criminal assaults, as a result of which employees sustained bodily injuries of various degrees of severity. The cases include 86 facts of assaults 
on the employees of the penal system [13, pp. 19-34] (in 2018 - 55 [12, p. 38], in 2017 - 46 [11, p. 39], in $2016-41$ [10, p. 33]), related to encroachment on personal security. During the last year alone, the increase in these encroachments was $36 \%$.

A sociological survey in this legal area was carried out with participation of 1,200 certified employees from various services and departments of institutions from 55 territorial bodies of the penal system, which represent all federal districts of the Russian Federation (Central District -13 bodies, Northwestern District -7 bodies, Southern District -4 bodies, North Caucasian District - 3 bodies, Volga District 11 bodies, Ural District -4 bodies, Siberian District -8 bodies, Far Eastern District -5 bodies). According to the survey, every fourth $(26.0 \%)$ respondent assesses their level of protection as high, the rest assess it as being low and average, which indicates that there are problems in the legal regulation and organization of activities to ensure state protection of employees of the penal system.

We understand the system of the legal phenomenon such as state protection of correctional officers and their relatives in its internal structure as a set of interrelated and interdependent elements and parts: actors, content, grounds, goals and procedure. The actors are the internal security units, special purpose departments and other divisions of the penal system. The content of the penal system is a set of security, social and legal protection measures provided for by Federal Law 45-FZ "On state protection of judges, officials of law enforcement and regulatory bodies" (hereinafter -the Law on State Protection). The legal basis for protection is the confirmed status of "protected person", and the actual assault on the life, health and property of employees of the penal system and their relatives in connection with the performance of their official duties. The purpose of protection is to ensure the rights and legitimate interests, to protect the life, health and property of penal system employees and their relatives, as well as to compensate for the damage caused. Procedure is the course of actions established by the Law on State Protection or other regulatory legal acts.

\section{Discussion}

A more detailed study of the issue of organizational provision of state protection of penal system employees requires reviewing foreign experience in this area, using the comparative method of cognition.
In the domestic legal field, normative legal acts have been adopted in the field of ensuring state protection of civil servants of law enforcement agencies, but we cannot assert that they are effectively implemented in practice. A special role in the development of this legislation belongs to the norms of international law and successful experience of foreign countries, which can be used in Russia.

Having reviewed foreign experience in the organization of state protection of penitentiary personnel, taking into account common features of state legal systems, organization of administration in penitentiary institutions in different countries, we can distinguish three significant groups of countries:

1) countries of the Commonwealth of Independent States (hereinafter referred to as the $\mathrm{CIS}$;

2) countries of the Asia-Pacific region;

3) European and North American countries.

In the former Soviet republics, the institute of state protection was developing in parallel with the legislation of Russia, while the Russian legislation in this area acts as a basic, initial legal instrument. Thus, at the end of 1998, at one of the meetings of the CIS member states, the Model Law on State Protection of Civil Servants in the Law Enforcement Sphere (hereinafter referred to as the Model Law) was adopted. This document is based on the generally recognized principles and standards of the United Nations and the Council of Europe in the field of state protection of civil servants, witnesses, victims and other participants in criminal proceedings.

A comparative analysis of this document and the Law on State Protection showed that the Model Law was reproduced in exact accordance with the original version of the domestic Law on State Protection dated April 20, 1995 [8, p.112].

The legislation of the CIS countries in the field of state protection of judges, law enforcement and regulatory officials is based on the provisions of the Model Law. Therefore, we believe that further research should focus on studying the experience of ensuring state protection of penitentiary personnel on the example of some countries of the two remaining groups. Among the countries in the Asia-Pacific region, we select Mongolia and Japan as examples and study their experience of protecting civil servants.

Let us look at the practice of the countries of the Asia-Pacific region.

The execution of criminal penalties in Mongolia is carried out by the General Directorate 
for the Execution of Judicial Decisions, which is part of the Ministry of Justice and Internal Affairs of Mongolia. Employees of penitentiary institutions in Mongolia are police officers; thus, state protection issues will be considered on the example of Mongolian police officers.

State protection of Mongolian police officers is based on the provisions of the Constitution of Mongolia. It contains provisions that establish social guarantees for police officers reaching old age, in case of disability, in case of caring for a child under three years of age and in other cases. Property damage caused to a police officer in connection with their execution of official duties is compensated by the police authorities, and subsequently, by way of recourse, is recovered from the guilty person.

The guarantees of state protection of judges and civil servants in the law enforcement sphere of Mongolia can be described as indirect protection measures. These measures, according to M. Bataev, "provide for the protection of the rights and legitimate interests of law enforcement officers through the implementation of law enforcement activities. Measures aimed at direct protection of the rights and legitimate interests of law enforcement officials are considered as the right granted by the state in certain cases to use personal weapons, physical force, special means, as well as to use other methods of protection not prohibited by law" [1, p.25].

Z. Tserenb at in his dissertation research on the legal and social protection of Mongolian police officers outlined and emphasized the relevance and importance of state protection of Mongolian police officers and the need to further improve its mechanisms. The author notes that the normative definition of measures of legal and social protection of state employees of law enforcement agencies is not consolidated. These state protection measures are contained in several laws of Mongolia ("On police bodies", "On public service", "On police service", "On social insurance of life and health of military personnel, citizens called up for reservist training, employees of the internal and border troops, police officers, state fire service, institutions and bodies of the penal system, intelligence officers", "On pensions, subsidies for military personnel", etc.) [14, pp. 55-56].

The provisions of the Law of Mongolia of February 1, 2014 no. 46 "On police service" are supplemented by by-laws, departmental orders, instructions, resolutions, which specify, elaborate on and explain the general provisions of this law, in particular the issues of social and legal protection of police officers.

On the basis of this law, in 2010, the Order of the Main Police Department of Mongolia no. 3691 was issued, which approved the "Guidelines for the protection of the interests of officials of the police and internal troops". This document contains the goals, objectives, directions of these activities, legal and organizational aspects of the implementation of its provisions, and also aims to increase the funding of these categories of state law enforcement officials. The tasks in the field of state protection are as follows:

- ensuring work safety, reducing occupational injuries;

- improving management, administration and staffing;

- protecting legitimate interests of police officers and members of the internal troops.

To fulfill the requirements specified in the Order, a department for the protection of the legitimate interests of officials of the police and internal troops was established, in 2012; it addresses the following tasks:

- development and adoption of legal and organizational mechanisms for the protection of the fundamental rights and freedoms of officials of the internal troops and police bodies;

- development of proposals for improving the mechanism for protecting the legitimate interests of employees of the internal troops and police officers;

- development of draft regulations, analysis and processing of proposals related to the elimination of violations of the rights and legitimate interests in the official activities of employees of the internal troops and police officers [15, pp. 148-150].

State protection of police officers also includes social protection. The measures of social protection of the staff of penitentiary institutions of Mongolia, which are contained in the Code on the Execution of Court Decisions, are as follows:

- in case of on-duty death of a correctional institution employee, their relatives and friends are paid a one-time payment in the amount of the official salary for five years;

- the staff of the institutions performing their duties around the clock is provided with free meals at the expense of the institution;

- additional bonuses to the monthly pay allowance (for working with prisoners, for long service in the state special service, for exceptional conditions of service, for the special rank, etc.). 
Social support measures in the framework of pension provision for police officers in Mongolia, provided for by the Law on Pensions and Benefits, are essential in strengthening the prestige of state service in the police; these measures include:

- the right to receive a pension with at least 25 years of work experience for men and at least 20 years for women;

- the amount of the pension is determined at the rate of $80 \%$ of the average monthly pay allowance;

- a pension supplement of $1.5 \%$ is established for each year of service beyond the period that entitles one to get a pension;

- upon retirement, a police officer receives a lump-sum allowance in the amount equal to the 36 times the amount of the monetary salary, half of which, if desired, can be obtained in advance before being released from service after the right to a pension arises [9, p. 50].

Protective measures for employees in Mongolia include almost exclusively social protection measures, while measures to ensure personal safety are neglected, except for necessary defense measures. This suggests that at the legislative level Mongolia should consider more carefully the issue of protecting employees in case of a threat to their life and health.

In Japan, the provision of state protection for judges, police officers, and correctional officers is regulated by a number of legal acts: the basic law of the State, the criminal and procedural codes, the laws on the Prosecutor's office, the police, and other acts. There is no consolidated legal act that would regulate relations arising in connection with the provision of state protection for law enforcement and regulatory officials. These activities are implemented in practice in the daily law enforcement activities of the national police.

According to $\mathrm{M}$. Button, a common practice in a number of foreign countries is when law enforcement officers appeal to private security structures to ensure their personal security [20, pp. 39-55]. In the event of threats against prison staff, the police may apply enhanced protective measures on the basis of a written request of a penitentiary officer. There is no statutory list of government employees subject to state protection in Japan. Only the current prime minister and the emperor have the legally established right to daily protection by special police [6, p. 45].

Thus, the legal framework for state protection of penitentiary personnel in Mongolia and
Japan does not have a separate unified form. The norms that establish the legal and social guarantees for penitentiary employees are contained in several laws and by-laws that specify them.

Having studied the experience of Mongolia and Japan in the implementation of protective measures against correctional personnel, we will focus on the final group - the countries of Western Europe and America.

The prototype of the Russian institution of state protection operates in many developed countries in Europe and in the United States.

It is worth noting the experience of organizing state protection in Italy. In this country, a certain system of bodies providing state protection has been formed, and a mechanism for including persons subject to state protection has been developed.

In Italy, the Central Protection Service is responsible for implementing security measures for protected persons. This unit was established as part of the Department of Public Security in 1991. It consists of four divisions that perform specific functions: whistleblower protection, witness protection, General Affairs Division, management and accounting. The General Affairs Division is responsible for supervising the activities of all the above-mentioned divisions, supports cooperation with foreign countries, provides legal, personnel, documentation, medical support, and carries out research work.

The Central Protection Service is the direct executor of a specific security measure (set of measures) in relation to the protected person, develops protection programs and decides on the application of the security measure (set of measures) The Commission is a collegial (advisory) body.

The advisory body is headed by an official of the Italian Ministry of Internal Affairs with the rank of deputy minister; it also includes judges, specialists with the necessary knowledge in the field of combating the mafia, as well as the prosecutor, who proposes the candidacy of the person to whom protective measures are being applied.

The complex of protective measures includes security measures and social guarantees, namely:

1. The main protective measure is to hide the protected person in a safe place. Due to open borders within the European Union, this measure can be implemented easily.

2. In addition to hiding an individual in a safe place, it may be necessary to provide them 
with new documents. The protected person receives new documents with a new name. New data are selected in accordance with the developed cover story, which the protected persons and their loved ones must strictly adhere to. Deviation from the established rules is the basis for the cancellation of security measures.

3. Change of personal data in information databases.

4. Provision of material assistance (monthly allowance and housing payment), etc. [3, p. 32].

The program does not have a set period of implementation; the reason for the program's termination is only the complete elimination of the threat. The decision to terminate the program is also made by the Central Commission.

Funding for this program has no restrictions. The Protection Service annually submits a financial report to the Central Commission; if necessary, funding is provided from the federal budget.

The financial and resource support of state protection, including the implementation of security measures, provided to the personnel of institutions and bodies of the penal system is carried out at the expense of federal budget funds allocated for the maintenance of penal institutions and bodies. In practice, the application of state protection measures in relation to penitentiary personnel is not of a daily nature; moreover, state bodies function under fiscal austerity; all this indicates that the financing of this expenditure item is carried out on a residual basis. The institution of state protection of judges, law enforcement officials and supervisory authorities does not have a consolidated independent state program for its financing. For example, the institution of state protection of victims, witnesses and other participants in criminal proceedings has an independent state funding program for the 2019-2023 period, the program is approved by the Resolution of the Government of the Russian Federation no. 1272 of October 25, 2018, which contains specific financial indicators of the costs for these purposes and their distribution among security agencies.

The funding of the state protection of judges, law enforcement and regulatory officials, including employees of the penal system, as part of an independent federal program, was supported by $47.8 \%$ of the respondents from among the employees of the penal system.

We think it would be undoubtedly interesting to review the experience of Germany in ensuring the security of protected persons. The experience of state protection of law enforcement agencies in this country, according to $D$. Mechko, is interesting from the point of view of implementing a protective measure in the form of keeping personal data about the protected person secret. When implementing protective measures, the competent authorities often face the problem of using biometric identification methods in various commercial organizations [19, pp. 189-199]. Fingerprints, iris scans, voice recognition systems, and other biometric data are used as identifiers for access to objects or certain rooms. All of the above, as well as the continuous development of technology in this area, negatively affects the secrecy of personal data of legend zed persons, and it becomes increasingly difficult for law enforcement agencies to ensure safety of the protected person [3, p.32]. State bodies should keep pace with the development of technology and improve technical support of their operational and service activities.

Due to these circumstances, the Russian authorities that ensure safety of protected persons need to improve protection mechanisms, taking into account the development of the high-tech sector; meanwhile, the issue of state funding and its volume is paramount in this regard.

In Germany, in the course of implementation of the witness protection program, which is carried out by special units that are part of the Federal Criminal Police Office and federated states' criminal police departments, some problems were identified in the application of such security measures as ensuring confidentiality and issuing new documents in relation to protected persons. The essence of the problem is that when the protected person changed personal data and documents, if the protected person has obligations to third parties (alimony, loan obligations, taxes, etc.) the rights of the latter were not taken into account, but were simply violated. In connection with these shortcomings, a provision was introduced, according to which the protected person is obliged to report on the existence of possible legal claims of third parties, and it is the duty of departments to ensure that the protected person contacts a third person in confidentiality in order to settle the claims that have arisen [7, pp.53-54].

In Austria, The Netherlands, and Germany, a decision on the implementation of state protection is made within three months, in the Russian Federation - within three days. Such a long period of time allows the competent law enforce- 
ment agencies to check more thoroughly the information about the presence of a threat and its reality and make a more informed decision. The downside of this position is that criminals will not need such a long time to implement their threats.

In many countries of the world, the activities aimed at increasing the level of state protection of officials of supervisory and law enforcement agencies and persons providing assistance to justice are concentrated in the hands of a specially created body, a single coordination center. For example, in the U.S. it is the United States Marshals Service within the U.S. Department of Justice, in Italy and Germany - special units of the criminal police. The multiplicity of measures taken to ensure the safety of protected persons, the implementation of coordinated analytical and methodological work that promotes the exchange of experience, makes it necessary to consolidate unified organizational and legal mechanisms [17, pp. 64-65]. According to O.A. Zaitsev, such a structure in Russia can be called the Department for State Protection of Officials and Certain Categories of Citizens.

From an economic point of view, the presence of the system of Russian law enforcement agencies that carry out state protection only at first glance contributes to cost saving. As practice shows, the implementation of state protection for these law enforcement agencies is not their usual function; consequently, it significantly reduces the productivity of the activities carried out and increases the cost of training personnel and providing material resources [4, p.53].

In our opinion, this proposal is also rational from the point of view of effectiveness of management activities, since the fragmented system of law enforcement agencies in Russia does not meet the requirement of a uniform approach in law enforcement practice.

Thus, $43.2 \%$ of respondents from the number of penitentiary employees point out that the problem of improving the effectiveness of state protection can be solved when these activities will be implemented by a single executive body. In particular, $10.2 \%$ of respondents spoke in favor of the Ministry of Internal Affairs of Russia, and $30.0 \%$ of respondents spoke in favor of the Federal Security Service of Russia. One of the alternative solutions may be to create special units on the basis of the Federal Service of the National Guard Troops (hereinafter - Rosgvardiya) to ensure the state protection of protected persons, since some special units (OMON, SOBR, etc.) are now under its jurisdiction.

The issue related to the importance of training personnel in specific techniques and methods of providing state protection in the law enforcement practice of the United States and Canada was noted by Melissa Kowalski. She points out that at the initial stage of the formation of the state protection units of the United States (the Marshals Service) and Canada (Royal Canadian Mounted Police), as part of the implementation of witness protection programs, they faced such a problem as the lack of trained personnel. Consequently, in several cases the use of protective measures could not save key witnesses from attacks by representatives of organized criminal communities, as a result of which the protected persons and law enforcement officers providing their protection were killed. In this regard, the units for training and advanced training for employees of the departments for the protection of participants in criminal proceedings were formed on the basis of these divisions [18, pp. 98-125].

In the course of training of law enforcement officials of many foreign countries, including America, the programs "Pedagogy of individual safety", "The will to survive", "Survival in the street" and others are used. Training in these programs is a prerequisite for every employee of the $\mathrm{FBI}$ and other law enforcement agencies [2, p. 34]. One of the reasons for this situation consists in a rather serious approach to training law enforcement officers. Thus, training begins with the formation of the readiness for the situation to take measures to ensure personal safety in professional and psychological terms $[16$, p. 7]. In other words, the employee is motivated to take personal (individual) measures to ensure their own safety.

According to I.S. Ivanov, another way to increase the effectiveness and validity of the implementation of security measures can be the establishment of a mandatory judicial procedure for making a decision on the application of security measures. Currently, in accordance with Part 1 of Article 14 of the Law on State Protection, such a decision is made by an official of the security agency [5, pp. 38-42].

\section{Results}

Summing up, we should note that the legal and organizational aspects of ensuring state protection of the personnel of penitentiary institutions in some foreign countries have strengths and weaknesses. Based on the analysis of this experience, we conclude that great attention 
is paid to the institution of state protection of persons who assist justice. Certain aspects of the organization of state protection of state servants in countries such as the United States, Germany, Italy and others can be used in the Russian Federation.

For the purpose of effective management and rational spending of funds, in our opinion, it is necessary to concentrate the existing potential of the institute of state protection in a single federal body that can function on the basis of Rosgvardiya.

To improve the effectiveness of implementation of the provisions of the Law on State Protection and ensure proper financial and logistical support for the implementation of state protection measures, we propose to adopt a state program for financing security measures for judges, law enforcement and regulatory officials for a period of five years (2022-2027) at the Government level. The program should provide for specific funding for the implementation of these measures and their distribution so as to carry out specific security measures.

Based on the experience of colleagues from Germany, we point out that the interests of other persons who have property and nonproperty claims (taxes, alimony, loans, etc.) to the protected persons should be taken into account and, if possible, resolved to the fullest extent. To implement this provision in practice, it is necessary to legally supplement the duties of the protected person with a provision on mandatory notification of the presence of property and non-property claims of third parties.

\section{REFERENCES}

1. Bataev M. Pravovoi status sotrudnika mongol'skoi politsii: teoretiko-pravovoiaspekt: avtoreferat dissertatsii na soiskanie uchenoi stepeni kandidata yuridicheskikh nauk [Legal status of an employee of the Mongolian police: theoretical and legal aspect: Candidate of Sciences (Law) dissertation abstract]. Saint Petersburg, 2005.25 p.

2. Budanov A.V. Obuchenie sotrudnikov pravookhranitel'nykh organov taktike $i$ metodam obespecheniya lichnoi bezopasnosti: uchebno-prakticheskoe posobie [Training of law enforcement officers in tactics and methods of ensuring personal security]. Moscow: Metodicheskii tsentr pri Glavnom upravlenii kadrov MVD Rossii, 1997. 56 p.

3. Vasilevskii A. The experience of European states in ensuring the security of persons subject to state protection (on the example of Italy and Germany). Professional, 2015,no. 3 (128), pp. 32-34.(In Russ.).

4. Zaitsev O.A. Teoreticheskie i pravovye osnovy gosudarstvennoi zashchity uchastnikov ugolovnogo sudoproizvodstva: dissertatsiya na soiskanie uchenoi stepeni doktora yuridicheskikh nauk [Theoretical and legal foundations of state protection of participants in criminal proceedings: Doctor of Sciences (Law) dissertation]. Moscow, $1999.446 \mathrm{p}$.

5. Ivanov I.S. Administrative and legal support for the security of participants in criminal proceedings in Russia Administrativnoe pravo i protsess=Administrative Law and Process, 2011, no. 11, pp. 38-42. (In Russ.).

6. Ivanov I.S. Relocation of the protected person to another permanent place of residence in domestic and foreign law. Rossiiskii sledovatel'=Russian Investigator, 2013, no. 6, pp. 41-47. (In Russ.).

7. Lukinskii A.V. Stanovlenie i razvitie instituta gosudarstvennoi zashchity (istoriko-pravovoe issledovanie): dissertatsiya na soiskanie uchenoi stepeni kandidata yuridicheskikh nauk [Formation and development of the institution of state protection (historical and legal research): Candidate of Sciences (Law) dissertation]. Moscow, 2013. 184 p.

8. Mel'nikova N.A., Kirilovskii O.V. Foreign experience of the CIS countries in providing state protection of personnel of penitentiary institutions. Wschodnioeuropejskie Czasopismo Naukowe, 2016, vol. 14, no. 3, pp. 112-116. Available at: https://www.elibrary.ru/download/elibrary_28082708_91867043.pdf (accessed February 24, 2021).

9. Navaan G. Features of the penitentiary system of Mongolia: tendencies of its reform. Mezhdunarodnyi penitentsiarnyi zhurnal=International Penitentiary Journal, 2015, no. 1, pp. 49-51. Available at: https://www.elibrary.ru/download/ elibrary_24927411_77694680.pdf (accessed February 24, 2021).(In Russ.).

10. Osnovnye pokazateli deyatel'nostiugolovno-ispolnitel'noi sistemy FSIN Rossii za 2016 god: informatsionnoanaliticheskii sbornik [Key performance indicators of the penitentiary system of the Federal Penitentiary Service of Russia for 2016: information and analytical collection]. Tver: FKU NIIIT FSIN Rossii, 2017. P. 33.

11. Osnovnye pokazateli deyatel'nosti ugolovno-ispolnitel'noisistemy FSIN Rossii za 2017 g.: informatsionno-analiticheskii sbornik [Key performance indicators of the penitentiary system of the Federal Penitentiary Service of Russia for 2017: information and analytical collection]. Tver: FKU NIIIT FSIN Rossii, 2018. P. 39.

12. Osnovnye pokazateli deyatel'nosti ugolovno-ispolnitel'noi sistemy FSIN Rossiiza 2018 g.: informatsionno-analiticheskii sbornik [Key performance indicators of the penitentiary system of the Federal Penitentiary Service of Russia for 2018 : information and analytical collection]. Tver: FKU NIIIT FSIN Rossii, 2019. P. 38.

13. Osnovnye pokazateli deyatel'nosti ugolovno-ispolnitel'noi sistemy FSIN Rossii za 2019 g.: informatsionno-analiticheskii sbornik [Key performance indicators of the penitentiary system of the Federal Penitentiary Service of Russia for 2019: information and analytical collection]. Tver: FKU NIIIT FSIN Rossii, 2020. Pp. 19-34.

14. Tserenbat Z. Administrativno-pravovaya zashchita sotrudnikov politsii Mongolii: dissertatsiyanasoiskanieuchenoistep enikandidatayuridicheskikhnauk [Administrative and legal protection of police officers in Mongolia: Candidate of Sciences (Law) dissertation]. Moscow, 2014.205 p.

15. Tserenbat Z. Fundamentals of administrative and legal protection of police officers in Mongolia. Vestnik Moskovskogo universiteta MVD Rossii=Bulletin of the Moscow University of the Ministry of Internal Affairs of Russia, 2013, no. 12, pp. 148-150. (In Russ.).

16. Chernov A.I. Organizatsiya lichnoi bezopasnosti sotrudnikov organov vnutrennikh del: uchebnoeposobie [Organization of personal security of employees of internal affairs bodies: a textbook]. Domodedovo: VIPK MVD Rossii, 2001. 76 p. 
17. Shiritov A.B. Gosudarstvennaya zashchita uchastnikov ugolovnogo sudoproizvodstva: problem ugolovnoprotsessual'nogo regulirovaniya: dissertatsiya na soiskanie uchenoi stepeni kandidata yuridicheskikh nauk [State protection of participants in criminal proceedings: problems of criminal procedure regulation: Candidate of Sciences (Law) dissertation]. Krasnodar, 2011.215 p.

18. Kowalski M.A. Hiring and training requirements for correctional officers: a statutory analysis. The Prison Journal, January 2020, vol. 100, no 1, pp. 98-125. DOI:10.1177/0032885519882342. Available at: https://journals.sagepub.com/ doi/full/10.1177/0032885519882342 (accessed February 20, 2021).

19. Mesko G. On some aspects of cybercrime and cybervictimization. European Journal of Crime, Criminal Law and Criminal Justice, 2018, vol. 26, no. 3, pp. 189-199. DOI: 10.1163/15718174-02603006. Available at: https://www.deepdyve.com/ Ip/brill/on-some-aspects-of-cybercrime-and-cybervictimization-QzXh8LLMr0?key=brill (accessed February 24, 2021). 20. Button M. The "New" private security industry, the private policing of cyberspace and the regulatory questions. Journal of Contemporary Criminal Justice, 2020, vol. 36, no. 1, pp. 39-55. DOI: 10.1177/1043986219890194. Available at: https:// journals.sagepub.com/doi/10.1177/1043986219890194\#articleShareContainer (accessed February 24, 2021).

\section{INFORMATION ABOUT THE AUTHOR}

OLEG V. KIRILOVSKII - Senior Lecturer at the Department of Administrative and Legal Disciplines, Faculty of Law, Vologda Institute of Law and Economics of FSIN Russia, Vologda, Russian Federation. ORCID: https://orcid.org/0000-0001-8718396X, e-mail: kirilovskiy77@mail.ru

Received February 24, 2021 